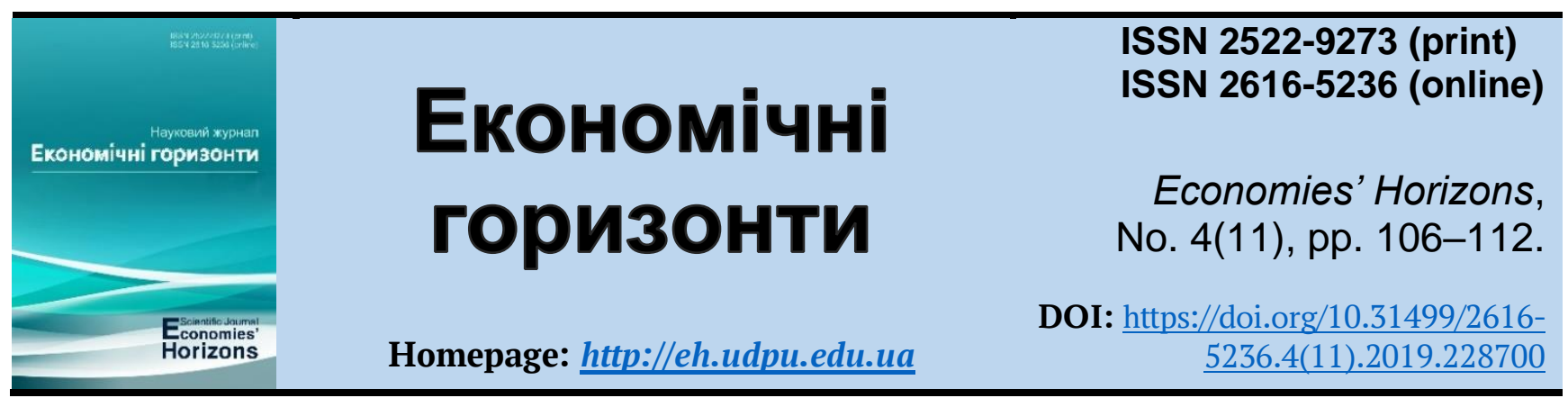

UDC 351/354:630.181/338.4:167

\title{
Methodological principles of making public management decisions in the sphere of forest ecosystem services
}

\author{
Nataliia V. Vasylieva ${ }^{1}$, Doc. Sc. Pub. Adm., Associate Professor \\ Victoria P. Zhuk ${ }^{2}$, Cand. Sc. Pub. Adm., Associate Professor
}

Received: 3 November 2019

Vasylieva, N. V. and Zhuk, V. P. (2019), "Methodological principles of making public management decisions in the sphere of forest ecosystem services", Economies' Horizons,

Accepted: 6 December 2019 no. 4(11), pp. 106-112, doi: https://doi.org/10.31499/2616-5236.4(11).2019.228700

\begin{abstract}
The purpose of the research. The purpose of study is the developing of methodological frameworks for public management decisions, in particular, for the feasibility of applying an ecosystem approach at the national, regional and local levels for solving problems and ensuring the development of forest ecosystem services, which will positively affect the welfare of the population. Methodology. The research methods (induction, deduction, objectivity, system, generalization) are used in article in order to present and justify the main results. Results. Today there is an urgent need to preserve biodiversity to reduce poverty and socio-economic development of individual regions and states, which requires strengthening environmental measures and balanced use of forest ecosystem services with the mandatory elimination of direct and indirect factors of change. Public management decisions should be made using an ecosystem approach and public involvement, which will allow timely identification and consideration of the preferences of different social groups. Practical meaning. The practical significance of the study lies in the applied nature of the proposed model for applying the ecosystem approach to public management decisions at the national, regional and local levels, which will solve the pressing problems of biodiversity conservation, ensure the development of forest ecosystems and have a positive effect on the well-being of the population, which will be devoted to our further research. Prospects for further research. There will be a search for effective ways to change the relation of a society to understand the importance of developing services of all four groups of forest ecosystem.
\end{abstract}

Keywords: public management decisions, ecosystem, forest ecosystem services, sustainable development, ecosystem approach.

JEL Classification: D6, Q28, Q57, Q58.

Number of references: 12; number of tables: 1; number of figures: 1; number of formulas: $\mathbf{0}$.

\footnotetext{
${ }^{1}$ National Academy for Public Administration under the President of Ukraine; Professor at the Department of Regional Administration, Local Self-Government and Urban Management; ORCID ID: https://orcid.org/00000002-3128-7767; e-mail: mailto:vasilyeva.nadu@gmail.com.

2 V.I. Vernadsky Taurida National University; Associate Professor at the Department of Economics, Entrepreneurship and Natural Sciences; ORCID ID: https://orcid.org/0000-0002-3284-959X; e-mail: japha@ukr.net.
} 


\title{
Методологічні засади прийняття публічно-управлінських рішень у сфері послуг лісових екосистем
}

\author{
Наталія Вікторівна Васильєва ${ }^{1}$, д. н. держ. упр., професор \\ Вікторія Петрівна Жук ${ }^{2}$, к. н. держ. упр., доцент
}

Стаття надійшла: 03.11.2019 Стаття прийнята: 06.12.2019
Vasylieva N. V., Zhuk V. P. Methodological principles of making public management decisions in the sphere of forest ecosystem services. Економічні горизонти. 2019. № 4(11). C. 106-112. DOI: $10.31499 / 2616-5236.4(11) \cdot 2019.228700$

Анотація. Мета дослідження. Мета дослідження полягає у розробці методологічних засад щодо прийняття публічно-управлінських рішень, зокрема обгрунтовано доцільність застосування екосистемного підходу на національному, регіональному та місцевому рівнях до вирішення проблеми збереження біорізноманіття i забезпечення розвитку послуг лісових екосистем, що позитивно позначитися на добробуті населення. Методологія. У статті застосовувались методи наукового дослідження: індукції, дедукції, об’єктивності, системний, узагальнення, які дозволили викласти й обгрунтувати основні результати. Результати. В умовах сьогодення гостро стає потреба у збереженні біорізноманіття для зменшення масштабів бідності й соціально-економічного розвитку окремих регіонів і держав, що потребує посилення заходів 3 охорони навколишнього середовища й збалансованого використання послуг лісових екосистем із обов'язковим ліквідуванням прямих і непрямих чинників змін. Публічно-управлінські рішення мають прийматися із застосуванням екосистемного підходу та залученням громадськості, що дозволить вчасно виявляти та враховувати уподобання різних соціальних груп. Практичне значення дослідження полягає у прикладному характері запропонованої моделі застосування екосистемного підходу до прийняття публічно-управлінських рішень на національному, регіональному та місцевому рівнях, що дозволить вирішити нагальні проблеми збереження біорізноманіття, забезпечення розвитку лісових екосистем і позитивно позначиться на добробуті населення. Перспективами подальших досліджень буде пошук дієвих шляхів до змінити відношення суспільства щодо розуміння важливості розвитку послуг усіх чотирьох груп лісових екосистемі.

Ключові слова: публічно-управлінські рішення, екосистема, послуги лісових екосистем, сталий розвиток, екосистемний підхід.

Кількість джерел: 12; кількість таблиць: 1; кількість рисунків: 1; кількість формул: 0.

\section{Introduction.}

The concept of "ecosystem services" is the object of attention of many domestic and foreign scholars of various fields of sciences, whose research is aimed at solving the problems of nature use and ensuring sustainable development of territories. However, this topic is relevant to politicians, public figures of different countries of the world. It has been established that the activities of people in the XX-XXI centuries significantly changed the ecosystem, which led to the degradation of ecosystem services, significant and sometimes irreversible losses in the diversity of life on earth. Therefore, the overwhelming majority of scientific research is analyzed and evaluating the impacts of ecosystem services and the well-being of the population on each other, the

\footnotetext{
1 Національна академія державного управління при Президентові України; професор кафедри регіонального управління, місцевого самоврядування та управління містом; ідентифікатор ORCID: https://orcid.org/0000-0002-3128-7767; e-mail:vasilyeva.nadu@gmail.com.

2 Таврійський національний університет імені В.І. Вернадського; доцент кафедри економіки, підприємництва та природничих наук; ідентифікатор ORCID: https://orcid.org/0000-0002-3284-959X; e-mail: japha@ukr.net.
} 
quality of natural resources management at the level of individual territories or countries. Life of people affects biodiversity leads to changes in ecosystems and ecosystem services.

\section{Problem setting.}

Solving the problem of preserving biodiversity and ensuring the development of forest ecosystems requires the introduction of an ecosystem approach to the adoption of public managerial decisions, the implementation of relevant measures at the national, regional and local levels, which will positively affect the overall welfare of the population

\section{Literature review.}

Significant attention of researchers is paid to the understanding of the content of the concept of "ecosystem services" (Mishenin and Degtyar, 2015; Shpyliova and Nosulich, 2016; Anisimova and Anisimov, 2019), detection of interdependence of ecosystems and welfare of the population (Millennium Ecosystem Assessment, 2005), evaluation of forest ecosystem services (Soloviy, 2009), formation of the concept of ecosystem approach to solve the problem of balancing ecological, economic and social components of sustainable development (Veklych, 2017), and the mechanism of state regulation of ecological and economic activity of subjects of natural resources (Horbyk, 2018; Yakymchuk, 2019). However, separate issues regarding the adoption of public managerial decisions in the field of forest ecosystems require a separate study.

\section{Methodology.}

The article used methods of scientific research: Induction, deduction, objectivity, systemic, generalization, which allowed to present and substantiate the main results.

\section{Research objectives.}

The purpose of the study is to develop methodological principles for the adoption of public managerial decisions, in particular, the expediency of using the ecosystem approach at the national, regional and local levels to solve the problem of preserving biodiversity and ensuring the development of forest ecosystems, which positively affect the well-being of the population.

\section{Results and discussions.}

Practice of the present demonstrates a significant negative impact of social environmental use on the environment: violations of self-regulation of state and deterioration of the quality of the natural system, therefore there is an urgent need to implement measures for the restoration and preservation of all components of the natural environment and the ecosystem as a whole. Therefore, the use of an ecosystem approach to social nature management should balance socio-ecological and economic systems, that is to provide a transition from onesided (complex) attitude to nature as a source of resources and involves the involvement of the relevant interested parties (Veklych, 2017, p. 55). In Ukraine there is a lack of state position and advocating national interests in carrying out economic activity in relation to natural resources, environmental protection, etc., which led to a number of environmental problems caused (The Verkhovna Rada of Ukraine, 2019):

- subordination of environmental priorities of economic expediency, failure to environmental consequences in normative legal acts and dominance of resource and energy-intensive sectors of the economy, which mainly negatively affect the environment, physical and moral demolition of fixed assets;

- unsatisfactory level of compliance with environmental legislation, the disadvantage of the inevitability of responsibility for its violation, lack of funding from state and local budgets of environmental measures, financing such measures at a residual principle;

- ineffective state administration in the field of environmental protection and regulation of the use of natural resources, inconsistency of actions of state executive authorities and local self-government bodies, the imperfection of the system of evaluation, monitoring and control;

- a low level of understanding in society Priorities for the preservation of the environment and benefits of balanced development, imperfection of the system of ecological education and enlightenment in the country, etc. 
The processes of globalization and public transformations have led to significant negative consequences, through which today public managerial decisions should be taken with the use of an ecosystem approach - this will achieve the goal of sustainable development, in particular to preserve and improve the existing state of biodiversity. The objectives of the state are a promising vision of its development and are reflected in managerial decisions that determine the relevant areas of activity. The application of this approach involves determining the goal(s) and the establishment of a certain hierarchy, substantiation of ways (directions) and optimal variant of achieving the goal(s), conducting a comprehensive analysis of the research object, detection of causal bonds, direct and indirect interdependent influences of man and ecosystem, assessment, monitoring and control over the achievement of the goal(s). In turn, in turn, it requires further application of the ecosystem (combining program-target and proactive) approach, which will allow you to better and effectively solve the problems of public administration in the field of forest ecosystems (Figure 1).

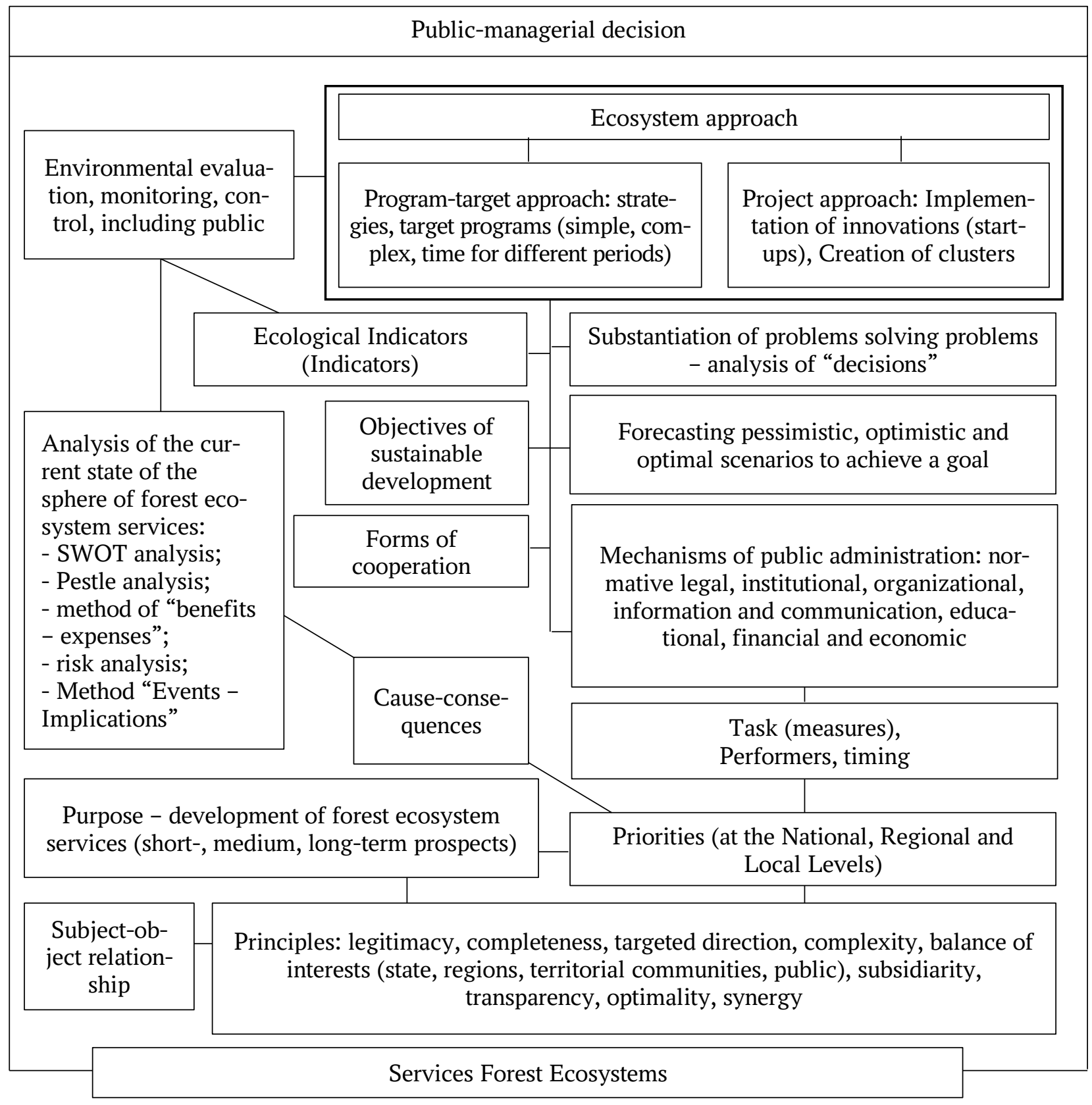

Fig. 1. Model of application of ecosystem approach to public managerial decisions

Source: Composed by the authors. 
Within our study, it is relevant to achievement of the goals of 13 "climate change" and 15 "preservation of land ecosystems", since forests are places of residence of many types of living organisms, a vital source of clean air and water, and can counter climate change, which occur in our country (UNDP in Ukraine, 2019). In Ukraine, in the forest ecosystem there are negative processes that manifests itself in excessive cutting of forests, the destruction of landscapes, unreasonable application of new technologies, which entails the formation of a significant amount of toxic and radioactive materials, radiation sources, the introduction of plant species and animals that increase and are found in Natural regions, illconstructed summer construction, disordered military activity, unsystematic development of transport infrastructure, etc. Intervention in the environment has violated the system of land use led to the threat of a catastrophic nature: changes in the hydrological and hydrothermal characteristics of landscapes, the complex of environmental factors of the environment, which is critical for many types of organisms and for ecosystems as a whole (Cabinet of Ministers of Ukraine, 2004).

Under the "ecosystem services" understand the "set of functions of ecosystems that ensure the preservation of the natural environment and create conditions for support and improvement of human life. Transforming into services, the functions of ecosystems acquire economic, socio-cultural and environmental characteristics and provide economic benefits both for consumers and suppliers of these services" (Shpyliova and Nosulich, 2016, p. 230); "the streams of economic benefits and values that receive economic entities and other stakeholders from the use of existing ecosystem functions, as well as those formed as a result of generating, recovery, support, regulation of ecosystem processes that are formed as a result of the purposeful activity of those or others. Business entities of various forms of ownership and levels of hierarchical management" (Mishenin and Degtyar, 2015, p. 248). These are all useful resources and benefits that a person can get from nature and satisfy their fundamental needs. Communities that invest in defense of biodiversity will receive significant dividends in the form of net environment, strong health of residents, rising real estate prices, increased numbers due to the arrival of young personnel, which in aggregate contributes to the socio-economic and cultural development of settlements. Their value may depend on various factors acting in specific conditions and manifest in economic, social, aesthetic, environmental and other aspects (Anisimova and Anisimov, 2019, p. 128).

The domestic forest industry plays a significant role in the socio-economic life of society. Forest ecosystem as unity of land, forest vegetation, animal world and other components of the environment performs a protective function of the environment and satisfies the environmental needs of citizens. However, in Ukraine there is a substrate situation in which the state of forest ecosystems does not meet the ecological and economic requirements (Horbyk, 2018, p. 11).

The services of forest ecosystems are closely related to the well-being of the population and represent social and environmental benefits from the use of existing resources, which are significantly dominated by economic benefits, as it contributes to primarily enriching and preserving cultural, spiritual and aesthetic aspects of society's well-being (Yakymchuk, 2019, p. 148). Reaching or degradation of forests leads to the emergence of environmental hazards and additional costs for society, caused, in particular floods and shifts, climate change, etc. at different levels of management (Soloviy, 2009, p. 79). Therefore, in the current conditions, it is acutely a need to preserve biodiversity to reduce the scales of poverty and socio-economic development of individual regions and states. This requires strengthening of environmental protection and balanced (sustainable) use of forest ecosystem services with mandatory liquidation of direct and indirect factors of change (Table 1). 
Table 1. Communication of services for forest ecosystems with well-being of the population

\begin{tabular}{|c|c|c|}
\hline Services Forest ecosystems & $\begin{aligned} \text { Factors of influence } \\
\end{aligned}$ & Welfare \\
\hline $\begin{array}{l}\text { Those providing products created by } \\
\text { ecosystems: food, water, wood, fibre, } \\
\text { etc. }\end{array}$ & $\begin{array}{l}\text { P - Political: Stability of the political situation, military action, } \\
\text { geopolitical relations, trading tariffs, quotas, support of domestic } \\
\text { manufacturer, level of corruption and bureaucracy, fiscal policy, } \\
\text { transparency of legislation }\end{array}$ & \multirow{6}{*}{$\begin{array}{l}\text { The reflection of } \\
\text { the various needs } \\
\text { of people, for } \\
\text { which conditions } \\
\text { for obtaining } \\
\text { good health (im- } \\
\text { munity), high- } \\
\text { paying work, op- } \\
\text { portunities for } \\
\text { recreation, recre- } \\
\text { ation and recrea- } \\
\text { tion, the realiza- } \\
\text { tion of its own } \\
\text { potential, etc. } \\
\text { must be created. }\end{array}$} \\
\hline \multirow{2}{*}{$\begin{array}{l}\text { Those regulating ecosystem processes: } \\
\text { cleaning and regulation of water, polli- } \\
\text { nation and distribution of seeds, affect } \\
\text { the climate: floods, natural disasters, } \\
\text { waste of human life, etc. }\end{array}$} & $\begin{array}{l}\text { E - Economic: Inflation, Economic Growth, Taxation, Unem- } \\
\text { ployment, Shadow Economics, Currency Exchange, State Target } \\
\text { Programs, Business Terms }\end{array}$ & \\
\hline & $\begin{array}{l}\text { S - socio-cultural: demographic indicators, level and distribution } \\
\text { of income, lifestyle, traditions, consumer purchasing power, atti- } \\
\text { tude towards work and recreation, level of education }\end{array}$ & \\
\hline $\begin{array}{l}\text { Those supporting conditions for life on } \\
\text { Earth: soil formation and preservation, } \\
\text { primary production, nutrient cycle }\end{array}$ & $\begin{array}{l}\mathrm{T} \text { - technological: new inventions, speed of technological up- } \\
\text { dates, energy resources, technology, infrastructure, development } \\
\text { and perception of society }\end{array}$ & \\
\hline \multirow{2}{*}{$\begin{array}{l}\text { Cultural - provide intangible benefits } \\
\text { received from ecosystems: rest and } \\
\text { tourism, cultural identity and diversity, } \\
\text { cultural landscapes and values of herit- } \\
\text { age, spiritual, aesthetic and inspira- } \\
\text { tional services }\end{array}$} & $\begin{array}{l}\text { L - legal: Impact of international legislation, inconsistency of } \\
\text { legislation rules, contradictions between normative and legal } \\
\text { documents, legislative initiatives, complexity of implementation } \\
\text { of the provisions }\end{array}$ & \\
\hline & $\begin{array}{l}\text { E - ecological: anthropogenic (influence of human activities), } \\
\text { abiotic (physical, chemical, climatic, etc., which are not } \\
\text { dependent on human and other living beings), biotic (set of influ- } \\
\text { ences of the life of some organisms to others, as well as in the } \\
\text { inanimate component of the surrounding environment. environ- } \\
\text { ments) factors }\end{array}$ & \\
\hline
\end{tabular}

Source: Composed by the author by material Millennium Ecosystem Assessment.

The combination of managerial decisions of the balanced system of economic, social and environmental indicators of achievement of the result indicates the provision of sustainable development of territories as the basis for their balanced functioning (Prylipko, 2019).

The problem of implementing accepted public and managerial decisions lies in the imperfection of purposefulness, which concerns planning and forecasting. Unsystematic and non-profile decisions lead to actions that violate the balance in the ecosystem. For example, an increase in production leads to an increase in water consumption or restrict access to other consumers, the deterioration of its quality, the enlargement of lands processed, the abuse of fertilizers, reducing the biological diversity and in particular forest cover. The transformation of forests in agricultural land changes the frequency and power of landslides, floods, busters, etc.

\section{Conclusions.}

Public-managerial decisions are the result of the implementation of managerial functions and their imperfection is due to the lack of an ecosystem approach to their adoption. In practice, there is a lack of coherent work in the formation and implementation of public administration mechanisms, in which individual components work separately or single. These mechanisms should be based on principles, approaches, methods and other components, and must be mutually agreed with each other, have the ability to quickly adapt to indeterminated conditions in public policy. This, in turn, will ultimately receive synergy effects (social, environmental and economic). The process of adopting public and managerial decisions should take place with the involvement of the public, which will allow to identify and take into account the preferences of various social groups: government and non-governmental bodies and organizations, business structures, institutions of education and science, culture and sports, health care and recreation, a local population, etc. Therefore, it is necessary to develop various forms of cooperation (communication) and 
apply innovative technologies. The ecosystem approach to accepting public and managerial decisions is based on a number of principles and application of a complex of methods. This affects a clearer definition of the goal, priorities (at different levels of management), qualitative formulation of target programs and projects, development of various forms of cooperation, which are based on subject-object relations) in order to achieve sustainable development purposes, in particular regarding development. Spheres of forest ecosystems. This will allow conceptually to change the relation of society to understand the importance: the development of services of all four forest ecosystem groups, a coherent attitude to the use of forest potential (cutting out of the forest leads to catastrophic consequences), as well as to ensure the welfare of the population at a high level, which, in turn, is determining indicator of state development.

\section{References}

Anisimova, S. V. and Anisimov, S. V. (2019), "Ecosystem services as a basis for the development of recreational activities”, Bulletin of Kharkiv National Automobile and Road University, no. 85, pp. 124-131, doi: https://doi.org/10.30977/BUL.2219-5548.2019.85.0.124

Cabinet of Ministers of Ukraine (2004), Order of the Cabinet of Ministers of Ukraine "Concept of the National Biodiversity Conservation Program for 2005-2025, available at: https://www.kmu.gov.ua/npas/9110364 (Accessed 22 October 2019)

Horbyk, V. M. (2018), "Methodological principles of state regulation of ecological and economic activity in the regions", Publichne administruvannya: teoriya ta praktyka, no. 2(20), pp. 1-13.

Millennium Ecosystem Assessment (2005), Ecosystems and Human Well-being: Synthesis. Island Press, Washington, DC, available at: https://www.millenniumassessment.org/documents/document.791.aspx.pdf (Accessed 22 October 2019)

Mishenin, Ye. V. and Dehtyar, N. V. (2015), "Economics of ecosystem services: theoretical and methodological foundations", Marketing and Management of Innovations, no. 2, pp. 243-257.

Prylipko, S. M. (2019), Rozvytok obsluhovuyuchoyi kooperatsiyi silskykh terytoriy: teoriya ta praktyka [Development of service cooperation of rural areas: theory and practice], Avhust Treyd, Kyiv, Ukraine, 372 p.

Shpyliova, Yu. B. and Nosulich, T. M. (2016), "Ecosystem services in the system of stimulating sustainable development of territories", Ekonomika pryrodokorystuvannia i okhorony dovkillia, pp. 228-236, available at: http://nbuv.gov.ua/UJRN/epod 2016201630 (Accessed 22 October 2019)

Soloviy, I. P. (2009), "Comparative assessment of forest ecosystem services in different regions of Ukraine", Naukovyy visnyk NLTU Ukrayiny, no. 19.6, pp. 79-85.

The Verkhovna Rada of Ukraine (2019), The law of Ukraine "On the basic principles (strategy) of the state environmental policy of Ukraine for the period up to 2030", available at: https://zakon.rada.gov.ua/laws/show/2697-19\#Text (Accessed 22 October 2019)

UNDP in Ukraine (2019), "Sustainable development goals", available at: https:/www.ua.undp.org/content/ukraine/uk/home/sustainable-development-goals.html (Accessed 22 October 2019)

Veklych, O. O. (2017), "The essence and content of the concept of "ecosystem approach" in economics", Ekonomika Ukrayiny, no. 12(673), pp. 52-67.

Yakymchuk, O. F. (2019), "State policy in the context of climate changes: Assessment of ecosystem services for the balanced development of territories", Investytsiyi: praktyka ta dosvid, no, 4, pp. 145-151, doi: https://doi.org/10.32702/2306-6814.2019.4.145

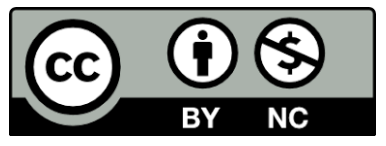

Цей твір ліцензовано на умовах Ліцензії Creative Commons «/з Зазначенням Авторства - Некомерційна 4.0 Міжнародна» (CC BY-NC 4.0). This is an open access journal and all published articles are licensed under a Creative Commons "Attribution-NonCommercial 4.0 International" (CC BY-NC 4.0). 